\title{
The Low Opportunity Costs of the Amazon Soy Moratorium
}

\author{
Lisa L. Rausch ${ }^{1 *}$ and Holly K. Gibbs ${ }^{1,2}$ \\ ${ }^{1}$ Center for Sustainability and the Global Environment, Nelson Institute for Environmental Studies, University \\ of Wisconsin-Madison, Madison, WI, United States, ${ }^{2}$ Department of Geography, University of Wisconsin-Madison, Madison, \\ WI, United States
}

Brazil's Amazon Soy Moratorium (ASM) contributed to overall reductions in Amazon deforestation since its implementation in 2006. Under the ASM, the Amazon soy sector maintains access to the growing share of the market that operates under zerodeforestation commitments. The ASM has been criticized as unfair to law-abiding producers. Only $1 \%$ of the approximately 14,000 soy farms in the Amazon Biome have soy-suitable, forested areas that could be deforested lawfully (49,273 ha). More than half of Amazon soy farms have soy-suitable areas that were deforested before 2008 and used for soy in 2019 (1.7 Mha). Taken together, these findings suggest that the opportunity costs of the ASM on current soy farms are low relative to the market access benefits.

\section{OPEN ACCESS}

Edited by:

Metodi Sotirov,

University of Freiburg, Germany

Reviewed by:

Paul Richard Furumo,

Stanford University, United States Nehru Prabakaran,

Wildlife Institute of India, India

*Correspondence:

Lisa L. Rausch

IIrausch@wisc.edu

Specialty section:

This article was submitted to

Tropical Forests,

a section of the journal

Frontiers in Forests and Global

Change

Received: 26 October 2020 Accepted: 09 March 2021

Published: 29 March 2021

Citation:

Rausch LL and Gibbs HK (2021)

The Low Opportunity Costs of the

Amazon Soy Moratorium.

Front. For. Glob. Change 4:621685.

doi: 10.3389/ffgc.2021.621685
Keywords: Brazil, agriculture, supply chain policy, deforestation, soy

\section{INTRODUCTION}

Brazil is a major global producer of soybeans and the world's leading soy exporter. Cultivation of soybeans is the second largest economic land use in the Brazilian Amazon, after cattle, and was historically an important driver of deforestation. However, the 2006 Amazon Soy Moratorium (ASM), helped to nearly eliminate direct deforestation for soy and contributed to the conservation of as much as 1.8 Mha of forest (Greenpeace, 2006; Heilmayr et al., 2020). Meanwhile, the total area planted to soy in the Amazon increased from 1.6 to 4.7 Mha between 2006 and 2019 (Macedo et al., 2012; Gibbs et al., 2015; GLAD [Global Land Analysis and Discovery], 2019).

Recently, the future of the ASM has become uncertain, as members of the current government have joined the Brazilian soybean farmers association, Aprosoja, in issuing public statements critical of the policy. These parties claim that the agreement violates national sovereignty by placing market sanctions on producers that deforest legally under Brazilian law (Aprosoja, 2019; Samora, 2019). Soybean traders, however, have defended the ASM through their trade association, Abiove, suggesting that ending it could lead to backlash from global consumers and place the sector's growing participation in export markets at risk (Samora, 2019; zu Ermgassen et al., 2020).

We explored the opportunity costs of the ASM to Brazilian soy farmers by assessing land use outside of protected areas in the Brazilian Amazon biome. Here we define opportunity costs as the foregone ability to deforest areas otherwise potentially permissible to clear under Brazil's Forest Code. We emphasize the most overt opportunity costs, those coming from forgone clearing on soy properties, which are the areas we assumed soy farmers would prefer to maximize. We also quantified potential forgone clearing outside of soy properties, though use of these lands for soy is less likely. In addition, we estimated the extent of previously cleared land that is both compliant under the ASM and suitable for soy, both on and nearby soy properties. 
We overlaid Brazil's PRODES deforestation maps, a soy suitability map, and Landsat-based maps of soy extent with a database of publicly available property maps, which covered $78 \%$ of the total soy extent in 2019 (GLAD [Global Land Analysis and Discovery], 2019; INPE [Instituto Nacional de Pesquisas Espaciais], 2020). The soy suitability map, which was used to identify areas that are biophysically suitable for cropland expansion, was produced using the methods described in Brandão et al. (2020) to merge a $30 \times 30 \mathrm{~m}$ grid cell map of areas with and without restrictions for growing soy and a $60 \times 60 \mathrm{~m}$ resolution map with integer values indicating degree of suitability (Soares-Filho et al., 2014; Rudorff and Oliveira, 2016). Property maps from three public sources were combined to produce a single map with public cadaster data from INCRA taking priority in the case of overlaps of boundaries between sources, followed by boundaries of those properties undergoing regularization in the Terra Legal program, and finally boundaries of properties in the Rural Environmental Registry (commonly known by its Portuguese-language acronym of CAR) (SFB [Serviço Florestal Brasileiro], 2017; INCRA [Instituto Nacional de Colonização e Reforma Agrária], 2020; SEMAS [Secretaria de Estado de Meio Ambiente e Sustentabilidade], 2020; SEMA [Secretaria de Estado de Meio Ambiente], 2020). This prioritization is because the INCRA cadaster and Terra Legal datasets are created using field-based GPS data points and, as such, are thought to be more precise than CAR boundaries, which are largely selfdeclared in an online registration portal (Freitas et al., 2018). CAR properties that could be identified as INCRA settlements were removed as well as those whose centroid fell within a federal or state protected area, but all other boundaries, including individual properties within settlement areas, were retained to minimize subjectivity in the analysis (IUCN [International Union for Conservation of Nature], 2020). Inaccuracies in remaining property boundaries could have led to over- or underestimates of numbers of properties or land extents presented below.

Property boundaries were identified as "soy properties" when they overlapped with at least 25 ha of soy extent in 2019; all other property boundaries were considered to be "non-soy properties." We assessed the distribution of Amazon forests (i.e., those areas not identified by PRODES as having been deforested) that were protected exclusively by the ASM as well as those protected by the Forest Code among soy and non-soy properties. We also assessed the distribution of ASM-compliant areas that may be available for soy expansion on and off of soy properties to better understand land constraints imposed by the ASM.

\section{FEW SOY FARMS CAN LEGALLY DEFOREST SUITABLE AREAS}

Our results demonstrate that the ASM rarely restricts the expansion of production area on soy properties beyond the limits already in place from the Forest Code and from the biophysical suitability requirements for growing soybeans. Instead, we show that the opportunity costs of the ASM are low for most producers in the Amazon. As of 2019, only 1.3\% (185) of the more than 14,000 soy farms in the Amazon had forested areas that were both eligible for legal clearing ("surplus") under the Forest Code (i.e., total forested area of the property exceeded the mandated $80 \%$ cover) and suitable for soy (Table 1). Nearly all of these properties were located in Mato Grosso (Figure 1). The suitable, surplus forest area on Amazon soy properties totaled 49,273 ha, which was roughly $1 \%$ of the soy extent in the Amazon.

\section{SOY PROPERTIES AND REGIONS HAVE ASM-COMPLIANT LAND FOR EXPANSION}

Previous research has shown that deforestation for soy is unnecessary in the Amazon due to the biome's large bank of suitable, cleared land (Gibbs et al., 2015; Brandão et al., 2020). Our results show that soy farms are an important source of these lands. Indeed, $60 \%$ of soy farms (8,799 properties) had at least 10 ha that was deforested prior to 2008 and was suitable but not used for soy. The total bank of suitable deforested land on soy properties amounted to 1.7 Mha that soy farmers could use for expansion on their current properties and equated to 36 times the area of potential ASM opportunity costs (i.e., suitable, surplus forested land on Amazon soy farms, as described above). Of the soy properties with suitable, surplus forest, most also had stores of ASM-eligible cleared land that could still be planted with soy (146 of the 185 properties). The total amount of ASM-eligible cleared land on these 146 properties was 22,593 ha. Planting soy on all 1.7 Mha of remaining ASMeligible cleared lands on current soy properties would increase the Amazon biome's soy area by 38\% over 2019 totals, though much of this expansion would come at the expense of pasture and other land uses.

Additional ASM-compliant soy areas are also available adjacent to current soy properties, suggesting the existence of additional opportunities for continuing expansion of soy beyond the boundaries of current soy properties in the Amazon (Figure 2). We identified another 8 Mha of suitable areas that were cleared prior to the ASM cutoff date of 2008 and located within $25 \mathrm{~km}$ of any soy property, but not on a soy property, which amounts to nearly twice the 2019 soy extent (Tables $\mathbf{1}, \mathbf{2}$ ). These additional areas may be reasonably accessible to soy farmers who have exhausted the expansion potential on their current properties, whether due to the ASM or to other limitations.

\section{ASM PROTECTS FORESTS OUTSIDE OF SOY PROPERTIES}

Most surplus forested land that is suitable for soy was located outside of soy properties (Figure $\mathbf{1}$ and Table 1). We identified 27,119 non-soy properties that could clear legally as of 2019, and 24,278 of these had soy-suitable forested areas. These non-soy properties with suitable, surplus forests amounted to only $5 \%$ of the total number of nonsoy properties and contained just over 3.6 Mha of suitable, surplus forest land (equivalent to approximately $75 \%$ of the 2019 soy area) (Table 1). Nearly one third of this land 
TABLE 1 | Summary of property-level land cover estimates.

\section{Production type}

2019 Soy farms

2019 Non-soy farms
Total number

Total number with soy-suitable forest area that could be cleared legally under the Forest Code

Suitable forest area that could be cleared legally

ASM-eligible area not planted to soy in 2019

Total number

Total number with soy-suitable forest area that could be cleared legally

Suitable forest area that could be cleared legally

Area of suitable forest in the Amazon outside of registered properties and protected areas

ASM-eligible area within $25 \mathrm{~km}$ of any soy farm, but not planted to soy in 2019
Quantity

14,575

185

49,273 ha

$1,762,513$ ha

545,303

24,278

$3,630,232$ ha

$49,445,173$ ha

$7,901,805$ ha

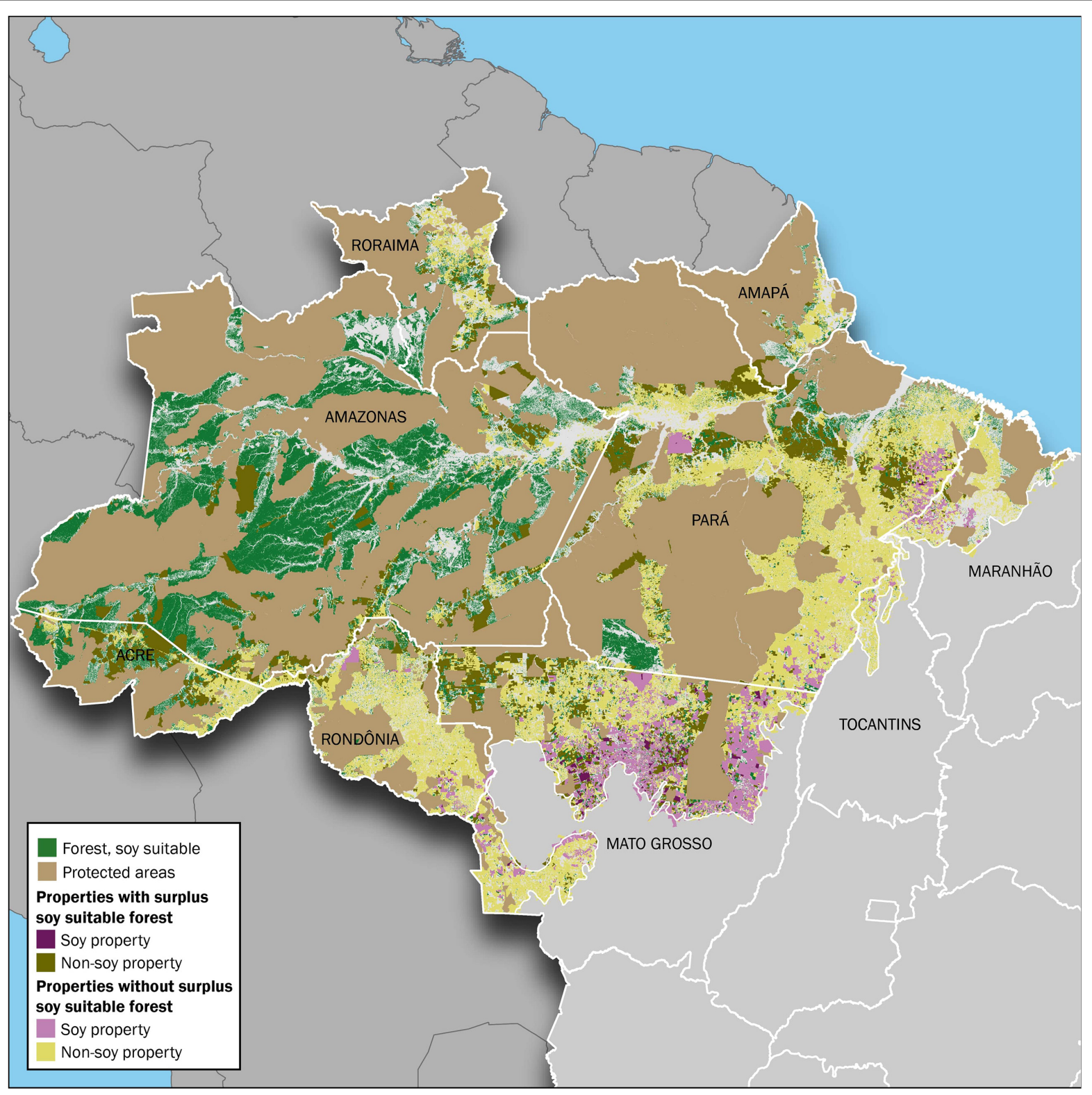

FIGURE 1 | Soy and non-soy producing properties with and without soy-suitable surplus forest. 
TABLE 2 | Amazon land cover classes outside of protected areas.

\begin{tabular}{lc}
\hline Land cover class & Area (ha) \\
\hline Soy & $4,680,490$ \\
Forest, soy suitable & $76,966,711$ \\
Deforestation pre-2008, soy suitable & $20,768,910$ \\
Deforestation 2008-2019, soy suitable & $3,873,568$ \\
Forest, not soy suitable & $48,477,506$ \\
Deforestation pre-2008, not soy suitable & $26,512,147$ \\
Deforestation 2008-2019, not soy suitable & $2,577,613$
\end{tabular}

(more than $1 \mathrm{Mha}$ ) was found on properties in Pará, which was also the state with the largest number of such non-soy properties $(10,022)$.
Another 49 Mha of forests that met basic suitability requirements for soy were located outside of both registered property boundaries and protected areas; some portion of this area may be eligible for legal clearing, but property boundaries are needed to assess this. Most unregistered but suitable forests were located in the state of Amazonas (36 Mha; 76\%), where soy production is unlikely to expand in the near future. However, the Amazon's dominant soy producing state, Mato Grosso, held 2.4 Mha of unregistered forests with soy suitability (5\% of the total), while another 6 Mha (13\%) were located in the Amazon's other top soy producing states of Pará and Rondônia.

Protection of surplus forest by making it ineligible for future soy production and, therefore, lowering the economic value of speculative clearing, may be one of the main mechanisms of the ASM's efficacy in protecting forests (Merry et al., 2008). The

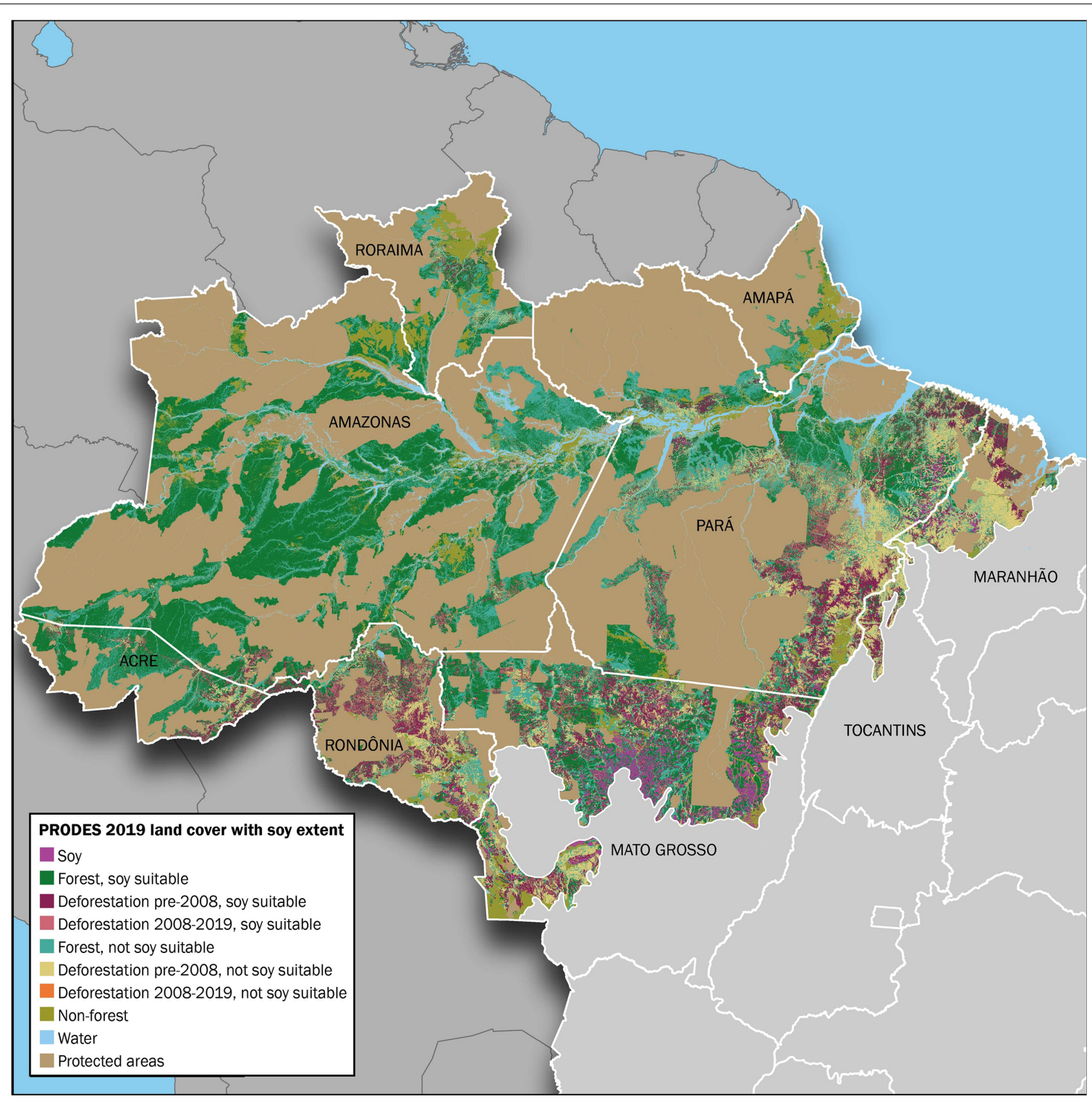

FIGURE 2 | Land cover in the Amazon according to soy suitability. 
ASM's prohibition on the use of these areas for soy production could generate increased costs for soy farmers hoping to expand onto new properties because they can only use potentially higherpriced properties with land that was first cleared over 15 years ago (Rausch and Gibbs, 2016).

\section{DISCUSSION}

Brazil is under increasing pressure to strengthen its efforts to combat deforestation. For example, in the wake of widespread Amazon fires in 2019 and 2020, Brazil's soy sector has faced calls for divestment, along with the cattle sector, in which implementation of Zero Deforestation Agreements has been incomplete (Gibbs et al., 2016; Alix-Garcia and Gibbs, 2017; Spring, 2020). The European Union has also withheld ratification of a trade agreement with South America's trade bloc, Mercosur, over Brazil's failure to address accelerating commodity-driven deforestation (Rajão et al., 2020). However, the ASM has remained a bright spot for Brazil's reputation as an environmental steward. International consumers of Brazil's soy, along with several major investors, have pointed to the maintenance of the ASM as a condition for continued business with the sector despite growing concerns about deforestation (Jolly and Ambrose, 2019).

Under the ASM, Brazil's Amazon soy sector maintains access to the increasingly large share of the market operating under zero-deforestation commitments. For example, as of 2019, 484 major companies, including traders, manufacturers, and retailers with exposure to "forest risk" commodities such as soy, have made some commitment to improve the sustainability of their supply chains, 72 of which were commitments to fully eliminate deforestation (Rothrock et al., 2019). Among these companies are the six major soy traders who are responsible for nearly $60 \%$ of Brazilian soy exports (Rothrock et al., 2019). Meanwhile, the share of Amazon soy production that is exported has increased from 78 to $95 \%$ from 2006 to 2018 (Trase [Transparency for Sustainable Economies], 2020). Thus, politically driven efforts to dismantle the ASM could lead to disruptions in the market for Amazon soy, with little to gain for most Brazilian soy producers, since few of them face immediate restrictions on their activities beyond those already imposed by the Forest Code and by biophysical limitations for suitability.

Ending the ASM would be especially unproductive given the policy's low opportunity costs. The ASM ensures that the

\section{REFERENCES}

Alix-Garcia, J., and Gibbs, H. K. (2017). Forest conservation effects of Brazil's zero deforestation agreements undermined by leakage. Glob. Environ. Chang. 47, 201-217. doi: 10.1016/j.gloenvcha.2017. 08.009

Aprosoja (2019). Governo Alega Ameaça à Soberania Nacional e Apoia Fim da Moratória da Soja. Available online at: http://www.aprosoja. com.br/comunicacao/noticia/governo-alega-ameaca-a-soberania-

nacional-e-apoia-fim-da-moratoria-da-soja (accessed October 23, 2020).

Brandão, A. Jr., Rausch, L., Durán, A. P., Costa, C. Jr., Spawn, S. A., and Gibbs, H. K. (2020). Estimating the potential for
Amazon's soy supply chains are free of even legal deforestation, but the costs are low because only 5\% of Amazon properties have any surplus forest and fewer than half of these have surplus forests that are also soy suitable. Soy farms are especially unlikely to have suitable surplus forests and are surrounded by suitable, long-cleared areas onto which soy can still expand. Given the region's accelerating deforestation crisis, farmers could risk losing access to major portions of the market if the ASM were to be canceled. Maintaining the ASM allows the Brazilian soy sector to retain its place as a leader in both production and conservation.

Calls are also intensifying for a sectoral commitment to halt clearing for soy in the Cerrado, which is responsible for at least $22 \%$ of the annual clearing in that biome (Rausch et al., 2019; Soterroni et al., 2019). The opportunity costs for soy farmers are higher than in the Amazon but similarly favor adoption of a Zero Deforestation Agreement, even considering the greater amount of Cerrado deforestation permitted under the Forest Code (Rausch et al., 2018, 2019). Meanwhile, France has recently passed a sweeping due diligence law, which holds major companies operating within its borders accountable for deforestation anywhere in their supply chains, and the European Union is pushing ahead with legislation to eliminate deforestation in imports of several major commodities including soy (Collinet, 2020; EC [European Commission], 2020; EP [European Parliament], 2020). These developments may further raise the stakes for the soy sector to carefully consider the costs of both ongoing Cerrado deforestation and threats to the ASM.

\section{AUTHOR CONTRIBUTIONS}

LR designed the research. LR and HG conducted the analysis and wrote the manuscript. Both authors contributed to the article and approved the submitted version.

\section{FUNDING}

This research was funded by Gordon and Betty Moore Foundation (Grant No. 1810027) and the Norwegian Agency for Development Cooperation's Department for Civil Society under the Norwegian Forest and Climate Initiative (Grant No. 706055).

conservation and farming in the amazon and cerrado under four policy scenarios. Sustanability 12:1277. doi: 10.3390/su120 31277

Collinet, J. (2020). Due Diligence: Has France Really Laid the Foundations to End Corporate Impunity? Equal Times. Available online at: https://www.equaltimes. org/due-diligence-has-france-really\#.X4-aLdBKhPY (accessed October 20, 2020).

EC [European Commission] (2020). Deforestation and Forest Degradation Reducing the Impact of Products Placed on the EU Market. Available online at: https://ec.europa.eu/info/law/better-regulation/have-your-say/initiatives/ 12137-Minimising-the-risk-of-deforestation-and-forest-degradationassociated-with-products-placed-on-the-EU-market/public-consultation (accessed October 22, 2020). 
EP [European Parliament] (2020). Report With Recommendations to the Commission on an EU Legal Framework to Halt and Reverse EU-Driven Global Deforestation. Available online at: https://www.europarl.europa.eu/ doceo/document/A-9-2020-0179_EN.html (accessed October 23, 2020).

Freitas, F. L. M., Englund, O., Sparovek, G., Berndes, G., Guidotti, V., Pinto, L. F. G., et al. (2018). Who owns the Brazilian carbon? Glob. Chang. Biol. 24, 2129-2142.

Gibbs, H. K., Munger, J., L’Roe, J., Barreto, P., Pereira, R., Christie, M., et al. (2016). Did ranchers and slaughterhouses respond to zero-deforestation agreements in the Brazilian amazon? Conserv. Lett. 9, 32-42. doi: 10.1111/conl.12175

Gibbs, H. K., Rausch, L., Munger, J., Schelly, I., Morton, D. C., Noojipady, P., et al. (2015). Brazil's soy moratorium: supply chain governance is needed to avoid deforestation. Science 347, 377-378.

GLAD [Global Land Analysis \& Discovery] (2019). Data From: Quantifying Spatio-Temporal Trends in the Expansion of South American Agriculture, 1985 to Present. Available online at: https://glad.geog.umd.edu/soyprob/ (accessed March 17, 2021).

Greenpeace (2006). Eating up the Amazon. Available online at: https://www. greenpeace.org/usa/research/eating-up-the-amazon/ (accessed April 21, 2006).

Heilmayr, R., Rausch, L. L., Munger, J., and Gibbs, H. K. (2020). Brazil's Amazon soy moratorium reduced deforestation. Nat. Food 1, 801-810. doi: 10.1038/ s43016-020-00194-5

INCRA [Instituto Nacional de Colonização e Reforma Agrária] (2020). Acervo Fundiário. Available online at: http://acervofundiario.incra.gov.br/acervo/acv. php (accessed March 17, 2021).

INPE [Instituto Nacional de Pesquisas Espaciais] (2020). Data From: PRODES: Monitoramento do Desmatamento da Floresta Amazônica Brasileira por Satélite. Available online at: http://www.obt.inpe.br/OBT/assuntos/programas/ amazonia/prodes (accessed March 17, 2021).

IUCN [International Union for Conservation of Nature] (2020). World Database of Protected Areas. Available online at: https://www.protectedplanet.net/country/ BRA (accessed March 17, 2021).

Jolly, J., and Ambrose, J. (2019). UK Firms Urge Brazil to Stop Amazon Deforestation for Soy Production. Available online at: https://www.theguardian. com/environment/2019/dec/03/uk-firms-urge-brazil-to-stop-amazondeforestation-for-soy-production (accessed October 22, 2020).

Macedo, M. N., DeFries, R. S., Morton, D. C., Stickler, C. M., Galford, G. L., and Shimabukuro, Y. E. (2012). Decoupling of deforestation and soy production in the southern amazon during the late 2000s. Proc. Natl. Acad. Sci. U.S.A. 109, 1341-1346. doi: 10.1073/pnas.1111374109

Merry, F., Amacher, G., and Lima, E. (2008). Land values in frontier settlements of the Brazilian amazon. World Dev. 36, 2390-2401. doi: 10.1016/j.worlddev. 2007.11.014

Rajão, R., Soares-Filho, B., Nunes, F., Börner, J., Machado, L., Assis, D., et al. (2020). The rotten apples of Brazil's agribusiness. Science 369, 246-248.

Rausch, L., and Gibbs, H. K. (2016). Property arrangements and soy governance in the Brazilian state of Mato Grosso: implications for deforestation-free production. Land 5:7. doi: 10.3390/land5020007

Rausch, L. L., Gibbs, H. K., Schelly, I., Brandão, A. Jr., Morton, D. C., Filho, A. C., et al. (2019). Soy expansion in Brazil's cerrado. Conserv. Lett. 12:e12671.

Rausch, L. L., Schelly, I., Hall, S., and Gibbs, H. K. (2018). Conversion-Free Soy Agreements: Potential Impacts on Farms in the Cerrado. Available online at: http://www.gibbs-lab.com/wp-content/uploads/2018/11/Infographic_
Estimating_Cerrado_Farmer_Opportunity_Costs_August2018.pdf (accessed March 17, 2021).

Rothrock, P., Weatherer, L., and Zwick, S. (2019). Corporate Commitments to Zero Deforestation: Company Progress on Commitments That Count, eds S. Stephen Donofrio and K. Hamrick (Washington, DC: Forest Trends).

Rudorff, B., and Oliveira, L. (2016). Geospatial Analyses of the Annual Crops Dynamic in the Brazilian Cerrado Biome. Available online at: https://www.idhsustainabletrade.com/uploaded/2016/04/Geospatial_analyses_ of_the_annual_crops_dynamic_in_the_brazilian_Cerrado_biome.pdf (accessed October 25, 2020).

Samora, R. (2019). Brazil Farmers Push Traders to End Amazon Soy Moratorium. Reuters. Available online at: https://www.reuters.com/article/us-brazilsoybeans-moratorium/brazil-farmers-push-traders-to-end-amazon-soymoratorium-idUSKBN1XF2J6 (accessed October 20, 2020).

SEMA [Secretaria de Estado de Meio Ambiente] (2020). SIMLAM (Sistema Integrado de Monitoramento e Licenciamento Ambiental) Mato Grosso. Available online at: http://monitoramento.sema.mt.gov.br/simlam/ (accessed March 17, 2021).

SEMAS [Secretaria de Estado de Meio Ambiente e Sustentabilidade] (2020). Cadastro Ambiental Rural do Estado do Pará. Available online at: http://car. semas.pa.gov.br/\#/ (accessed March 17, 2021).

SFB [Serviço Florestal Brasileiro] (2017). Sicar-Sistema Nacional de Cadastro Ambiental Rural. Available online at: http://www.car.gov.br/\#/ (accessed March 17, 2021).

Soares-Filho, B., Rajão, R., Macedo, M., Carneiro, A., Costa, W., Coe, M., et al. (2014). Cracking Brazil's forest code. Science 344, 363-364.

Soterroni, A. C., Ramos, F. M., Mosnier, A., Fargione, J., Andrade, P. R., Baumgarten, L., et al. (2019). Expanding the soy moratorium to Brazil's cerrado. Sci. Adv. 5:eaav7336. doi: 10.1126/sciadv.aav7336

Spring, J. (2020). Exclusive: European Investors Threaten Brazil Divestment Over Deforestation. Reuters. Available online at: https://www.reuters.com/article/ us-brazil-environment-divestment-exclusi/exclusive- european-investorsthreaten-brazil-divestment-over-deforestation-idUSKBN23Q1MU (accessed October 22, 2020).

Trase [Transparency for Sustainable Economies] (2020). Data From: Brazil: Soy. Available online at: https://trase.earth/explore (accessed March 17, 2021).

zu Ermgassen, E. K. H. J., Ayre, B., Godar, J., Bastos Lima, M. G., Bauch, S., Garrett, R., et al. (2020). Using supply chain data to monitor zero deforestation commitments: an assessment of progress in the Brazilian soy sector. Environ. Res. Lett. 15:035003. doi: 10.1088/1748-9326/ab6497

Conflict of Interest: The authors declare that the research was conducted in the absence of any commercial or financial relationships that could be construed as a potential conflict of interest.

Copyright (C) 2021 Rausch and Gibbs. This is an open-access article distributed under the terms of the Creative Commons Attribution License (CC BY). The use, distribution or reproduction in other forums is permitted, provided the original author(s) and the copyright owner(s) are credited and that the original publication in this journal is cited, in accordance with accepted academic practice. No use, distribution or reproduction is permitted which does not comply with these terms. 